\title{
General practice at the margins: a student's experience of homelessness
}

There is an awkward silence as I close the door to a small, windowless room and ask Steven to take a seat. Sitting forward with elbows propped on his knees and hands clasped, he rocks slightly in anticipation, looking me over, perhaps waiting for me to judge. I smile and ask how he's doing today. He sits back in the chair, crosses his legs and tells me his story.

\section{STEVEN'S STORY}

Steven is 29 years old and a recovering intravenous drug user. He is currently on probation and struggling to find stable accommodation. He is just one of the many thousands of people in the UK who will find themselves homeless this winter. I ask him to describe how he came to be here today.

When he was 9 years old, Steven was sexually abused and with little support from family or friends his school life began to deteriorate. He turned to cannabis in order to 'numb the anxiety and torment of it all'. Following expulsion from school, he associated himself with a local gang, slipping into harder drugs and petty crime.

For Steven, it was the dealers who perpetuated this familiar cycle:

'They manipulate their clients by claiming they have no cannabis but offer cocaine at a cheaper price instead. They'd then offer heroin to calm you from your high and once hooked, they'd crank up the prices.'

Soon Steven began stealing to fund his habit and at 16 years of age, he was given a custodial sentence. With little support on his release, he was forced to 'skipper' (sleep rough or flit from place to place in order to fnd a bed for the night) the homeless scene, an environment that fuelled his addictions. Thus a depressingly mundane cycle of crime, prison, and homelessness began.

I could feel his discomfort and sadness at looking back and his desperation to make a better future for himself. For Steven it became clear he could not do it alone. The homeless services are an opportunity for helping him to stabilise his erratic and volatile way of life.

\section{HOMELESSNESS AND HEALTH}

For people like Steven, who have already been rejected, or banned from other services, the homeless practice is their final stop. The causes and effects of homelessness are complex and include social, financial, and psychological issues. Therefore a truly holistic service is required. During my attachment I witnessed how this was put into practice from day to day.

Homeless people often flit between cities and may go off the radar for a while. This can challenge 'mainstream services'. In order to accommodate the chaotic lifestyle and comorbidity of this population, the practice offers a multidisciplinary team at a 'one-stop shop' under one roof. I sat in with GPs, nurses, dentists, podiatrists, psychiatric nurses, social workers, psychologists, mental health nurses, and midwives who all provided flexible drop-in clinics without a conventional appointment system.

Although multidisciplinary care is increasingly common in the NHS, it is rare to see it work as effectively as it does here, particularly with such a complex patient group. I saw how staff worked together opportunistically to ensure that health problems were identified and treatment initiated promptly. I could appreciate how this could build a spirit of trust and mutual respect between patients and professionals.

\section{OUT ON THE STREETS}

Over the next few weeks I visited numerous homeless hostels around Edinburgh. As well as providing accommodation and meals these also offered human contact. I spoke with 'key workers' who are available to help people like Steven. Steven's key worker Ruth helps him organise medical and social work appointments and accompanies him on his journey towards controlling his drug use and finding stable accommodation. Steven says this crucial human contact gives him a solid support which he did not have when growing up.

At the extremes of health care I saw how the NHS is supported, and in some places replaced by voluntary agencies. I saw for myself how health care needs to reach beyond the walls of the surgery. For those in crisis, the Bethany Trust provides hot meals and accommodation in the local church halls and The Cowgate centre runs a night shelter.

Sadly, for those who do find housing it can prove difficult to cope with such an unfamiliar environment and some end up back on the streets. When Steven was allocated a house a few years ago, he had led an institutionalised life and had few living skills. He found it difficult to cope with everyday responsibilities, such as paying bills and attending medical appointments and gradually slipped back into the homeless scene.

\section{WELFARE, ADDICTION, AND MENTAL HEALTH}

Through meeting people like Steven I realised that the 'homeless' are not a single group. Each individual has their own tale to tell and their own health problems. For an observer such as myself it is impossible to ignore the inextricable links between mental health, poverty, addiction, and housing.

When Steven's girlfriend became pregnant, she attended a drop-in clinic at 'The Access Point' who were able to fasttrack her into stable accommodation. With the support of social services, the team could ensure she would be more able to provide for the new baby. I saw how staff met together at weekly 'Child Welfare' meetings to share information and plan ongoing care and support needs for extremely vulnerable families.

The GP sign's Steven's benefit application under grounds of 'drug dependence'. Other patients' certificates 
alluded to 'mental health problems' that precluded them from stable employment. I encountered many patients at different stages of addiction. I realised that there is no easy solution. Many patients find it difficult to engage with services regularly and staff tried to strike a balance between reactive and proactive care.

Even for those who do stabilise their drug use, it takes time and perseverance to reach a balance that the patient can cope with. Steven had been on a methadone programme and was progressing well until life events shook him and he relapsed. This is a common pattern that I saw where an individual's circumstances met with their inability to cope.

Mental health problems in homeless patients are often complex and comorbid. I could see how these could result from and give rise to homelessness. One of the psychiatric nurses at the clinic suggested to me that 'three quarters of homeless patients require mental health assessment and that the majority of these have a history of sexual abuse.' In many patients, this trauma triggers an understandable route of escape through the use of drugs or alcohol.

I saw too how the homeless are no more immune to world events than each of us. I met with war veterans who suffered PTSD. Some of these were young men, not much older than me, who are returning from recent conflicts.

\section{REFLECTION}

Meeting people like Steven led me into a world that many medical students and young doctors would never have the opportunity to experience. I was given the chance to witness ethical dilemmas and social justice issues for which there are no clear answers. These are topics that are often taught in the classroom rather than on the streets.

This experience taught me a lot about life as well as medicine. Many medical students reach their final years still unsure of which field to practice in and some have limited life experience. As most teaching takes place in carefully 'quality assured' environments it was refreshing to step outside and spend time on the margins of general practice. It was inspiring also to spend time with people who share their passions enthusiastically and encourage students to engage with medicine as a human being. I was struck by their openness, flexibility, pragmatism, and mutual respect.

Throughout my training, the importance of teamwork and communication are continually emphasised but not always exemplified. My lasting impression of the homeless practice was its ethos of collaboration and the willingness of each member of staff to help one another despite the complexity and challenge of their case load.

I feel that this placement has been a pivotal point in my education. Not only has it reaffirmed where my interests lie but it has allowed me the opportunity to spend time talking with people on a personal level. Meeting each patient and hearing their story enabled me to gain an understanding of how patients arrive at different destinations in their life. I hope I will take this understanding with me when I encounter disadvantaged patients in other settings in the future.

As our conversation ends I thank Steven for his time. He will return now to his journey as I will to mine.

\section{Kirsty Duncan}

\section{Author's Note}

Steven is a fictional name in order to protect the identity of the patient discussed.

DOI: 10.3399/bjgp09X473024

\section{A conferring}

It was a sunlit day in November when the Provost and I arrived in Heathrow. We met up, quite accidently, on the way to receive our FRCGP parchments; Joe had been awarded his Fellowship in April, but, for whatever reasons, postponed his trip until November and I was glad of the company. The place hummed with excitement. We rubbed shoulders with everybody, but I was gobsmacked to be able to shake the hand of one of my career idols, John Horder, his name adorns the MRCGP cert, in its place of honour over my desk.

The event went off with military precision; opening remarks, honorary fellows and fellows; followed by members. We had arrived, had been peer reviewed, and found deserving of this great honour.

As I stood in line, I could feel my stomach churning, my chest expanding and a great feeling of pride filled my whole being. My heart raced as I heard my name being called and the short 25 word (exactly) citation being read out. I mounted the platform with a great leap (hoping not to trip) and was presented with my rolled parchment by the President. I know he said something nice in my ear, but, for the life of me, I can't remember what it was. The Provost was called later, not because he was any less deserving, but because we were called in alphabetical order, and a great cheer went up for him somebody had leaked that it was his birthday.

Following a short break, we were treated to one of the most thought-provoking lectures I have ever heard: the MacKenzie lecture was given by Martin Marshall and he discussed the role of general practice - past, present and future; an evolving masterpiece. This was followed by the AGM. At this point, Joe asked me up for some champers and I, after not too much persuasion, agreed. We toasted each other, the College, and all our fellow members, whom we hope will soon be jolly good fellows too!

It was a great day, a great experience and I would recommend it to all.

\section{Dermot Halpin}

The RCGP Annual General Meeting is on 20 November 2009.

DOI: 10.3399/bjgp09X473033 